\title{
Rituximab Use in Warm and Cold Autoimmune Hemolytic Anemia
}

\author{
Irina Murakhovskaya
}

Department of Hematology and Oncology, Albert Einstein College of Medicine/Montefiore Medical Center, Bronx, NY 10467, USA; imurakho@montefiore.org

Received: 19 November 2020; Accepted: 9 December 2020; Published: 13 December 2020

\begin{abstract}
Autoimmune hemolytic anemia is a rare condition characterized by destruction of red blood cells with and without involvement of complement. It is associated with significant morbidity and mortality. In warm autoimmune hemolytic anemia, less than $50 \%$ of patients remain in long-term remission following initial steroid therapy and subsequent therapies are required. Cold agglutinin disease is a clonal hematologic disorder that requires therapy in the majority of patients and responds poorly to steroids and alkylators. Rituximab has a favorable toxicity profile and has demonstrated efficacy in autoimmune hemolytic anemia in first-line as well as relapsed settings. Rituximab is the preferred therapy for steroid refractory warm autoimmune hemolytic anemia (wAIHA) and as part of the first- and second-line treatment of cold agglutinin disease. This article reviews the mechanism of action of rituximab and the current literature on its role in the management of primary and secondary warm autoimmune hemolytic anemia and cold agglutinin disease.
\end{abstract}

Keywords: autoimmune hemolytic anemia treatment; warm autoimmune hemolytic anemia; rituximab; cold agglutinin disease

\section{Introduction}

Autoimmune hemolytic anemia (AIHA) is a rare disorder with an estimated incidence of 0.8-3 per $10^{5}$ year in adults, and prevalence of 17 per 100,000 [1-3]. AIHA can present at any age but it is more common in adults with a peak incidence between 50 and 70 years [1]. AIHA is characterized by the production of antibodies directed against red cell antigens with consequent red blood cell destruction with or without the involvement of complement [4].

Autoimmune hemolytic anemia is classified as warm or cold (cold autoimmune hemolytic anemia and paroxysmal cold hemoglobinuria) based on the antibody class and thermal amplitude of the pathogenic antibodies. Warm autoimmune hemolytic anemia (wAIHA) accounts for $80 \%$ of the cases of AIHA in adults [5]. The pathogenic antibody is usually immunoglobulin of the IgG subtype, and a direct antiglobulin test (DAT) is positive for presence of IgG and in some cases C3d on the red cell surface, although it can be negative in $5 \%$ of cases [4,6]. Destruction of IgG-coated red blood cells (RBC) takes place in the spleen via Fc $\gamma$ receptor-mediated phagocytosis by splenic macrophages, antibody-dependent cell-mediated cytotoxicity, and complement-mediated hemolysis [7].

In cold AIHA, the pathogenic antibody is a cold agglutinin most often of the immunoglobulin $\mathrm{M}$ (IgM) subtype with I antigen specificity. Cold agglutinin fixes complement (C1q) below core body temperature and dissociates from the red cells as they move centrally, which leads to activation of the classical complement pathway and deposition of C3b on the RBC surface [8]. DAT is positive for presence of C3d. Complement-coated erythrocytes are subject to extravascular hemolysis via $\mathrm{C} 3 \mathrm{~b}$ receptors in the hepatic mononuclear phagocytic system. If a large amount of complement is generated, formation of the membrane attack complex leads to intravascular hemolysis. This process is generally limited by the presence of complement regulatory proteins (CD55 and CD59) on the red 
blood cell surface. In some cases of AIHA, both pathogenic IgG antibody and clinically significant cold agglutinin are present. Those are referred to as "mixed" AIHA. Paroxysmal cold hemoglobinuria is characterized by a biphasic cold-reacting IgG, which binds to patient RBCs in the cold; fixes complement; and dissociates at body temperature, causing hemolysis $[9,10]$.

In approximately $50 \%$ of cases, AIHA is associated with an underlying collagen vascular disease, lymphoproliferative disorder, infection, solid tumors, or medication, and in the other $50 \%$ it is idiopathic [11]. Autologous and allogeneic transplants [12-14], and immune checkpoint inhibitor therapy for solid tumors $[15,16]$, are emerging etiologies for AIHA.

A clinical course can be variable and severe with a reported mortality rate of $11 \%$ [17]. The degree of anemia depends on antibody characteristics, the activity of the mononuclear phagocytic system, and the bone marrow compensatory response $[1,18]$. Patients can experience acute or chronic hemolytic anemia; hemoglobinuria can be seen with significant complement involvement and intravascular hemolysis. The risk of thrombosis is increased in warm AIHA, particularly during the active phase of the disease [17,19], as well as in cold agglutinin disease [20,21]. In cold agglutinin disease, cold-induced intravascular agglutination results in circulatory symptoms such as acrocyanosis and/or the Raynaud phenomena, which occur in $50-90 \%$ of patients [22,23].

\section{AIHA Pathophysiology}

Multiple mechanisms are involved in the pathogenesis of AIHA. In warm autoimmune hemolytic anemia, B cell mediated immune dysregulation results in production of pathogenic autoantibodies, cytokines, as well as $\mathrm{T}$ cell activation [4,24]. In addition, $\mathrm{T}$ cell dysregulation results in loss of immune tolerance. Decreased levels of regulatory T cells (Tregs), which play a key role in the immunologic self-tolerance, are associated with autoreactivity in AIHA [25,26]. Altered Th1/Th2 balance in favor of Th1 lymphocytes has been demonstrated in patients with autoimmune hemolytic anemia [27]. Th17 cells, a subset of CD4+ T helper cells which secrete interleukin (IL)-17, have also been implicated in pathogenesis of AIHA and other autoimmune diseases [28]. Increased IL-17 secretion has been shown to be correlated with the disease activity in AIHA patients. [29]. Increased ratio of $\mathrm{T}$ follicular helper cells to $\mathrm{T}$ follicular regulatory cells, which are essential in the regulation of germinal center reactions and antibody production, were shown to play important role for control and induction of AIHA [30].

Unlike warm autoimmune hemolytic anemia, cold agglutinin disease (CAD) is a clonal hematologic disorder. Primary CAD is a distinct low grade lymphoproliferave disorder [31-33], with discernible histologic [31] and flow cytometric characteristics [32], immunoglobulin heavy and light chain gene features [33], cytogenetic abnormalities [34], and recurrent somatic mutations on next generation sequencing [35]. The pathogenic IgM is monoclonal, with kappa light chain specificity in $85 \%$ of cases $[22,36,37]$. Secondary cold agglutinin syndrome associated with B cell lymphoproliferative disorders is less common than primary CAD. In infection associated cAIHA, which is usually transient, IgM is polyclonal [38].

\section{Rituximab Mechanism of Action}

Rituximab is a chimeric anti-CD20 antibody that consists of human IgG1-kappa constant region and variable regions from the murine monoclonal anti-CD20 antibody [39]. The B-cell antigen CD20 is a transmembrane protein that is present in virtually all B cells from the stage of commitment to B-cell lineage to differentiation into plasma cells, at which point it is downregulated. [40].

Rituximab was initially developed as a therapy for CD20+ lymphoproliferative malignancies. Subsequently, efficacy was also demonstrated in autoimmune disorders such as rheumatoid arthritis (RA); systemic lupus erythematosus; multiple sclerosis; and several hematologic autoimmune diseases such as immune thrombocytopenic purpura (ITP), acquired hemophilia, thrombotic thrombocytopenic purpura, and AIHA [41-45]. In AIHA, rituximab demonstrated efficacy in the first line as well as 
relapsed setting $[43,46-52]$ in primary as well as secondary forms $[49,53]$ of wAHA, cold agglutinin disease, and secondary cold agglutinin syndrome.

Rituximab binding to CD20 on the B cell surface induces B cell apoptosis via direct signaling, activation of complement, and engagement of the cell-mediated cytotoxicity $[39,54]$. The resultant B cell depletion, which can persist for 6-12 months, [40,55] leads to suppression of B-cell mediated production of auto-Abs, cytokine secretion, and their APC function [56]. In addition to B cell depletion, rituximab has an immunomodulatory effect on cellular and innate immunity in autoimmune diseases. ITP therapy with rituximab has been associated with upregulation of the $\mathrm{T}$ reg cells and restoration of Th1/Th2 ratio [57-59]. In nephrotic syndrome, rituximab therapy was associated with decrease in Th17, Th2, and memory T cells, and increased Treg cells [60]. Clinical response to rituximab therapy in AIHA was found to be associated with decrease in Th1 cytokines interferon- $\gamma$, interleukin-12, tumor necrosis factor- $\alpha$, and IL-17, suggesting immunomodulatory activity of rituximab on Th1/Th2 balance [61].

\section{Treatment of Warm Autoimmune Hemolytic Anemia}

Management of WAIHA has historically been empirically derived or based on retrospective studies with paucity of randomized and prospective clinical trials $[1,62]$. Steroids have been used as a first line therapy with initial response rate of $70-80 \%[17,50,63]$. Up to $20-40 \%$ of patients have a durable remission after initial therapy, but the rest have a chronic, relapsing course $[2,17,64]$, requiring subsequent therapy [50].

Splenectomy has been used traditionally as a second-line therapy for wAIHA with initial response rates of $60-70 \%$ [65-67], and surgical mortality rate of $0.8 \%$ in recent studies [68]. However, long-term cure rates are only approximately $20 \%$ [2] with associated risk of infections due to encapsulated bacteria of 3.3-5\% [69,70]. Thrombotic complications [71] and pulmonary hypertension [72] are also increased in splenectomized patients. More recently, Rituximab has emerged as an effective therapy of wAIHA, replacing splenectomy as preferred modality in the second-line setting [7,73-77].

Additional therapeutic options in wAIHA include immunosuppressive agents. Azathioprine and cyclophosphamide have been used in relapsed setting with overall responses reported in one-third of patients [2,78]. These response rates are based on the retrospective studies and case reports and are subject to selection and publication bias. Responses to therapy with other immunosuppressive agents such as cyclosporine and mycophenolate mofetil have been reported as well, although data are limited [2].

Danazol was reported to produce responses both as a single agent and in combination with prednisone [79] in retrospective studies. Administration of erythropoietin has been successfully used in patients with refractory AIHA, particularly in the presence of reticulocytopenia [18]. Several novel agents are currently under investigation, including Syk inhibitor Fostamatinib [80], FcRn receptor inhibitors [81,82], and Bruton tyrosine kinase (BTK) inhibitors [83,84]. Figure 1 summarizes current therapeutic algorithm for wAIHA. 


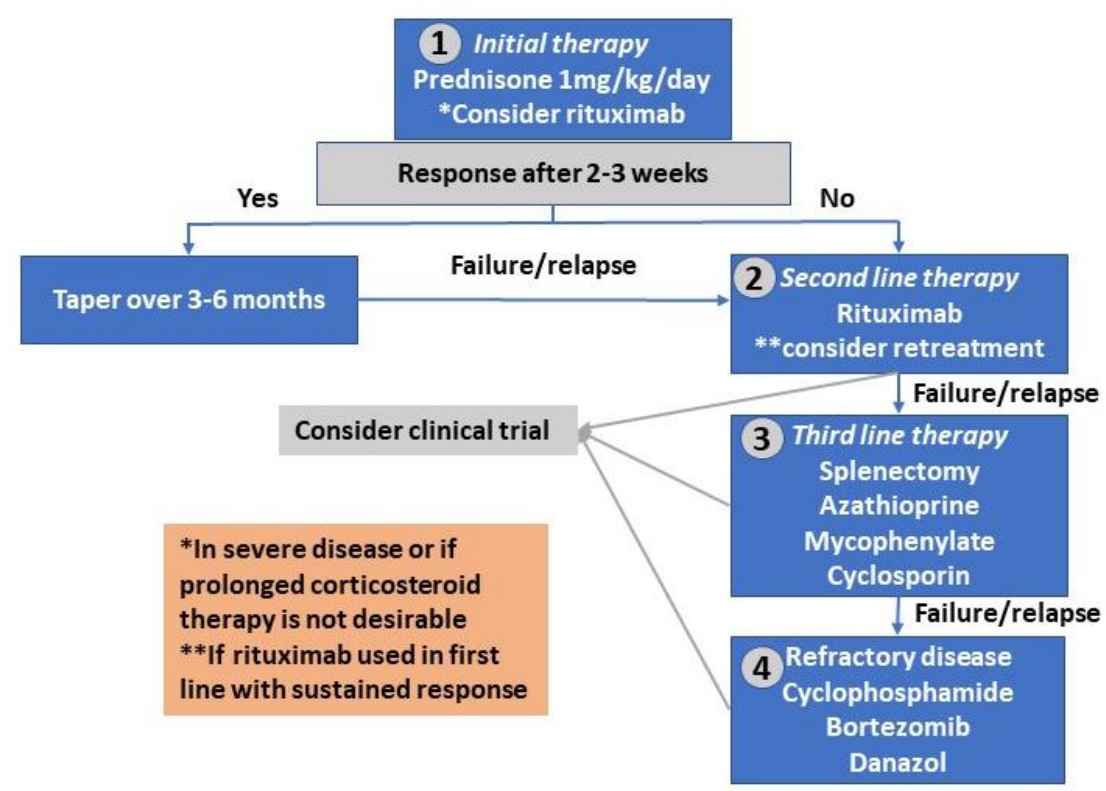

Figure 1. Treatment algorithm for warm autoimmune hemolytic anemia. “*” $=$ in severe disease or if prolonged corticosteroid therapy is not desirable; “**" $=$ if rituximab is used in the first line with sustained response.

\section{Rituximab in Warm Autoimmune Hemolytic Anemia}

\subsection{Relapsed/Refractory wAIHA}

In a small prospective pediatric study in 15 children with relapsed/refractory wAIHA, rituximab therapy was associated with an $87 \%$ response rate [85]. Several retrospective observational studies reported efficacy of rituximab in treatment of relapsed/refractory wAIHA. The largest studies that included primary wAIHA are summarized in Table 1. Rituximab demonstrated efficacy in patients with both primary and secondary AIHA with overall response rates (ORR) of 70-80\% in relapsed/refractory setting and a median duration of response of 1-2 years. Median time to response was 4 to 6 weeks after the first rituximab dose, with majority of patients responding within 4 weeks after the first dose $[48,86]$. Responses within the first week [49] and up to 3 months [86] were also seen. Complete response (CR) rates were more variable, ranging from 25 to $75 \%$, reflecting clinical heterogeneity of the disease. Relapse rate at $1-2$ years was $25-50 \%$ [43,86], with retreatment associated with responses $[49,85,86]$.

A meta-analysis of 21 observational studies that included adults or children with primary or secondary cold and warm AIHA treated with rituximab reported similar results, with overall response rate (ORR) of $79 \%$ and CR rate of $42 \%$ for wAIHA. CR rate was the highest within 2 to 4 months after rituximab initiation. Younger patients, and shorter duration of wAIHA, had a better response to rituximab treatment [87].

Table 1. Retrospective trials of rituximab in relapsed/refractory warm autoimmune hemolytic anemia (wAIHA).

\begin{tabular}{cccccc}
\hline First Author (Year) & $\begin{array}{c}\text { Number of } \\
\text { Patients }\end{array}$ & $\begin{array}{c}\text { Splenectomy } \\
\text { (N) }\end{array}$ & $\begin{array}{c}\text { ORR/CR } \\
\mathbf{( \% )}\end{array}$ & $\begin{array}{c}\text { Duration of } \\
\text { Response (mo) }\end{array}$ & Comment \\
\hline Narat (2005) [46] & 11 & 5 & $64 / 27$ & $2-20$ (median 11) & \\
\hline $\begin{array}{c}\text { D'Arena (2007) } \\
\text { [47] }\end{array}$ & 11 & 1 & $100 / 73$ & $\begin{array}{c}\text { All primary AIHA, } \\
\text { 2 patients received 3 } \\
\text { additional monthly doses } \\
\text { of maintenance R; } \\
\text { additional patient had } \\
\text { Rituxan retreatment for } \\
\text { ITP }\end{array}$ \\
\hline
\end{tabular}


Table 1. Cont.

\begin{tabular}{|c|c|c|c|c|c|}
\hline First Author (Year) & $\begin{array}{l}\text { Number of } \\
\text { Patients }\end{array}$ & $\begin{array}{l}\text { Splenectomy } \\
\text { (N) }\end{array}$ & $\begin{array}{c}\text { ORR/CR } \\
(\%)\end{array}$ & $\begin{array}{c}\text { Duration of } \\
\text { Response (mo) }\end{array}$ & Comment \\
\hline $\begin{array}{c}\text { Bussone (2009) } \\
\text { [48] }\end{array}$ & 27 & 6 & $93 / 30$ & NR & $\begin{array}{c}5(18 \% \text { relapses }) \text { after } \\
\text { median f/u } 20.9 \text { mo, } \\
3 \text { retreated with } \mathrm{R} \text { and } \\
\text { responded }\end{array}$ \\
\hline $\begin{array}{c}\text { Dierickx (2009) } \\
{[43]}\end{array}$ & 36 & 10 & $83 / 50$ & $\begin{array}{l}\text { 1yr PFS 72\% } \\
2 y r \text { PFS 56\% }\end{array}$ & \\
\hline $\begin{array}{c}\text { Peñalver (2010) } \\
\text { [49] }\end{array}$ & 27 & 13 & $77 / 61$ & $\begin{array}{l}\text { Duration of } \\
\text { response }>6 \mathrm{mo} \text { in } \\
\text { patients in } \mathrm{CR}\end{array}$ & \\
\hline $\begin{array}{c}\text { Maung (2013) } \\
{[86]}\end{array}$ & 34 & 3 & $71 / 27$ & $9-60$ & $\begin{array}{c}50 \% \text { relapse; median time } \\
\text { to next treatment } 16.5 \mathrm{mo} \\
28.5 \% \text { maintained } \\
\text { response at } 3 \text { years }\end{array}$ \\
\hline $\begin{array}{c}\text { Roumier (2014) } \\
\text { [50] }\end{array}$ & 25 & 2 & $80 / \mathrm{NR}$ & $\begin{array}{c}50 \% \text { relapse after a } \\
\text { mean of } 14 \pm 8\end{array}$ & $62 \%$ secondary wAIHA \\
\hline $\begin{array}{c}\text { Barcellini (2014) } \\
\text { [17] }\end{array}$ & 32 & NR & $81 / 56$ & & $\begin{array}{c}\text { Primary AIHA only } \\
\text { low dose } \mathrm{R}\end{array}$ \\
\hline $\begin{array}{c}\text { Jaime-Pérez (2019) } \\
\text { [52] } \\
\text { First-line } \\
\text { Relapsed }\end{array}$ & $\begin{array}{c}18 \\
8\end{array}$ & $\begin{array}{c}\text { N/A } \\
7\end{array}$ & $\begin{array}{l}100 / 83 \\
100 / 63\end{array}$ & $\begin{array}{c}\text { Median } 16.5 \\
\text { Mean maintained } \\
\text { response } 82 \pm 18\end{array}$ & $\begin{array}{l}\text { Low dose } \mathrm{R}+\text { high dose } \\
\text { dexamethasone } \\
(40 \mathrm{mg} / \text { day }) \text { for } 4 \text { days }\end{array}$ \\
\hline
\end{tabular}

$\mathrm{R}=$ rituximab; low dose rituximab: rituximab at $100 \mathrm{mg} /$ week for 4 weeks; $\mathrm{NR}=$ not reported; ORR = overall response rate; $\mathrm{CR}$ = complete response; $\mathrm{PFS}$ - progression free survival; ITP = immune thrombocytopenic purpura; $\mathrm{N} / \mathrm{A}=$ not applicable; $\mathrm{mo}=$ months.

\subsection{Rituximab as First Line Therapy of wAIHA}

Two prospective randomized phase III trials $[88,89]$ evaluated role of rituximab in the front-line setting. A Danish open-label randomized study compared rituximab with prednisolone with prednisolone monotherapy in 64 newly diagnosed primary wAIHA patients. Conventional lymphoma schedule of 4 weekly intravenous rituximab $375 \mathrm{mg} / \mathrm{m}^{2}$ infusions was administered. Addition of rituximab to prednisolone resulted in significantly higher response rates at 12 months ( $75 \%$ vs. 36\%) and improved relapse free survival at 36 months (70\% vs. $45 \%)$ compared to prednisolone alone [88].

A more recent randomized double-blind placebo-controlled trial in 32 adults with newly diagnosed primary wAIHA demonstrated similar results with higher efficacy (ORR 75\%/34\% CR) with rituximab compared to placebo (ORR 31\%/16\% CR). Two infusions of rituximab or placebo at a fixed dose of $1000 \mathrm{mg}$ were administered 2 weeks apart. Patients in both arms received prednisone $1 \mathrm{mg} / \mathrm{kg}$ day in the first 2 weeks [89]. Response duration was longer with rituximab compared to placebo, with 10/16 patients treated with rituximab and 3/16 patients in the placebo arm remaining in CR at 2 years.

\subsection{Rituximab Combination Therapy}

Rituximab combination therapy with cyclophosphamide and dexamethasone (RCD) demonstrated significant efficacy in chronic lymphocytic leukemia (CLL)-associated wAIHA [90,91]. This combination has also been evaluated in primary wAIHA. Response rate of $97 \%$ with CR $42 \%$ was reported by Bocian et al. in 19 wAIHA cases (12 primary AIHA and 6 treatment naïve) treated with RCD in the first line and relapsed setting [92]. Similar response rates were seen in 16 relapsed/refractory wAIHA with OR $94 \%$ and CR of $69 \%$ [93]. Among patients who achieved CRs, majority (64\%) had secondary WAIHA. The median duration of response was 9.8 months. Two patients required hospitalization for infection. Taking into consideration single agent rituximab activity in wAIHA, further studies are needed to evaluate the role of RCD in wAIHA therapy. 


\subsection{Rituximab in Secondary wAIHA}

Secondary wAIHA is most commonly seen in association with hematological malignancies, infection, immunodeficiency, and autoimmune disorders [50]. A general principle for therapy of secondary wAIHA is if the underlying disorder is clinically active, initial therapy should include treatment of underlying cause [74,77]. If underlying disease is adequately controlled, treatment of secondary wAIHA is generally similar to that of primary wAIHA.

Rituximab has shown efficacy in relapsed setting in CLL as a single agent [53] and in combination with cyclophosphamide and dexamethasone (RCD) [90,91]; cyclophosphamide, vincristine, and prednisone (CVP) [94]; and with bendamustine [95] with response rates of $80-100 \%$ and response duration of 22-24 months with combination therapy (Table 2). In AIHA associated with systemic lupus erythematosus (SLE) [96] and common variable immune deficiency (CVID) [97], responses are approximately $80 \%$, with majority being complete responses.

Table 2. Rituximab in secondary wAIHA.

\begin{tabular}{|c|c|c|c|c|c|c|}
\hline $\begin{array}{l}\text { Underlying } \\
\text { Condition }\end{array}$ & $\begin{array}{l}\text { First Author } \\
\quad \text { (Year) }\end{array}$ & Regimen & $\begin{array}{l}\text { Number of } \\
\text { Patients }\end{array}$ & $\begin{array}{c}\text { ORR/CR } \\
(\%)\end{array}$ & $\begin{array}{c}\text { Duration of } \\
\text { Response (mo) }\end{array}$ & $\begin{array}{l}\text { Line of } \\
\text { Therapy }\end{array}$ \\
\hline CLL & $\begin{array}{c}D^{\prime} \text { Arena } \\
(2006) \\
{[53]}\end{array}$ & $\mathrm{R} 375 \mathrm{mg} / \mathrm{m}^{2} \times 4$ & 14 & $72 / 22$ & NR & $\mathrm{R} / \mathrm{R}$ \\
\hline CLL & $\begin{array}{l}\text { Rossignol } \\
\text { (2011) } \\
\text { [90] }\end{array}$ & $\begin{array}{c}\text { rituximab, } \\
\text { cyclophosphamide, } \\
\text { and dexamethasone } \\
\text { (RCD) }\end{array}$ & 26 & $89.5 / 81$ & 24 & $\begin{array}{c}\mathrm{R} / \mathrm{R} \\
\text { (including } \\
\text { R-refractory }\end{array}$ \\
\hline CLL & $\begin{array}{c}\text { Kaufman } \\
(2009) \\
{[91]}\end{array}$ & $\mathrm{RCD}$ & $\begin{array}{c}7 \\
13\end{array}$ & $100 / 85$ & 22 & $\begin{array}{l}\text { 1st line } \\
\text { R/R }\end{array}$ \\
\hline CLL & $\begin{array}{c}\text { Bowen } \\
(2010) \\
{[94]}\end{array}$ & R-CVP & 17 & $100 / 82$ & 21.7 & $\begin{array}{c}\mathrm{R} / \mathrm{R} \\
\text { (including } \\
\text { R-refractory }\end{array}$ \\
\hline CLL & $\begin{array}{l}\text { Quinquenel } \\
\text { (2015) } \\
\text { [95] }\end{array}$ & R-bendamustine & $\begin{array}{c}25 \\
1\end{array}$ & $81 / 31$ & 28 & $\begin{array}{l}\text { 1st line } \\
\text { R/R }\end{array}$ \\
\hline $\begin{array}{l}\text { non-CLL } \\
\text { LPD }\end{array}$ & $\begin{array}{l}\text { Hauswirth } \\
\text { (2007) } \\
{[51]}\end{array}$ & R, R-chemo & 7 & $100 / 100$ & NR & $\mathrm{R} / \mathrm{R}$ \\
\hline SLE & $\begin{array}{l}\text { Serris (2018) } \\
{[96]}\end{array}$ & $\begin{array}{c}\mathrm{R}, \\
\text { R-immunosuppression }\end{array}$ & 16 & $87.5 / 75$ & $\begin{array}{l}\text { RFS } 62.5 \% \text { at } \\
2 \text { years }\end{array}$ & $\mathrm{R} / \mathrm{R}$ \\
\hline CVID & $\begin{array}{c}\text { Gobert } \\
(2011) \\
{[97]}\end{array}$ & $\mathrm{R}$ & $\begin{array}{c}5 \text { AIHA } \\
5 \text { AIHA/ITP }\end{array}$ & $\begin{array}{l}80 / 80 \\
80 / 40\end{array}$ & NR & $R / R$ \\
\hline $\begin{array}{l}\text { Transplant } \\
\text { associated }\end{array}$ & $\begin{array}{c}\text { Faraci } \\
(2014) \\
{[99]}\end{array}$ & $\begin{array}{c}\mathrm{R}, \\
\text { immunosuppression }\end{array}$ & 7 & $100 / 100$ & NR & $\mathrm{R} / \mathrm{R}$ \\
\hline $\begin{array}{l}\text { Transplant } \\
\text { associated }\end{array}$ & $\begin{array}{l}\text { Sanz }(2014) \\
{[98]}\end{array}$ & $\begin{array}{c}\mathrm{R}, \\
\text { immunosuppression }\end{array}$ & $\begin{array}{l}4 \\
4\end{array}$ & $\begin{array}{l}75 / 50 \% \\
50 \% / 0\end{array}$ & NR & $\begin{array}{l}\text { 1st line } \\
\text { R/R }\end{array}$ \\
\hline
\end{tabular}

$\mathrm{R}=$ rituximab; R-CVP-rituximab, cyclophosphamide, vincristine, and prednisone; R/R-Relapsed/Refractory. NR = not reported; $\mathrm{ORR}=$ overall response rate. $\mathrm{CR}=$ complete response. $\mathrm{RFS}$-relapse free survival. ITP $=$ immune thrombocytopenic purpura; AIHA = autoimmune hemolytic anemia; wAIHA = warm autoimmune hemolytic anemia; $\mathrm{mo}=$ months .

AIHA associated with non-CLL lymphoproliferative disorders has lower response rate to steroids, higher rates of steroid dependency, and higher likelihood to require second-line therapy [50,51]. Despite limited data, rituximab containing lymphoma-directed regimens are associated with higher probability of response [51]. Similarly, in AIHA associated with transplantation, responses to steroids are poor and front-line rituximab therapy is associated with better outcomes [98,99]. 


\section{Treatment of Cold Agglutinin Disease}

Corticosteroids have limited efficacy in treating CAD with response rates of $14-35 \%$ [17,22], and need high doses to maintain remission $[1,38,100]$. Cytototoxic immunosuppressive drugs such as chlorambucil or cyclophosphamide have been tried with limited efficacy, with partial responses seen in $16 \%$ patients in retrospective studies [22,101]. Splenectomy is not effective, since clearance of C3b-opsonized red blood cells occurs primarily in the liver [1,22].

Single agent rituximab as well as rituximab containing immunochemotherapy have significant activity and are currently recommended as first- and second-line therapy $[78,102]$ in CAD. Bortezomib has shown promising activity in a small prospective, non-randomized study of 19 patients with CAD. Responses were seen in $32 \%$ patients after a single cycle of therapy, with $16 \%$ complete responses [103].

Complement inhibition with antibody directed therapy against C5 with eculizumab [104], C3 with pegcetacoplan [105], and most recently C1s sutimlimab [106] has shown efficacy and is further being explored in clinical trials $[107,108]$. In the phase $1 b$, first-in-human trial in patients with CAD treated with four weekly doses of sutimlimab, 7 out of 10 patients responded with a hemoglobin increase $>2 \mathrm{~g} / \mathrm{dL}$. Responses were rapid with median increase in hemoglobin levels of $1.6 \mathrm{~g} / \mathrm{dL}$ within the first week, and $3.9 \mathrm{~g} / \mathrm{dL}$ within 6 weeks. All previously transfused patients achieved transfusion independence [109]. These responses were recapped in a named patient program in responders with every 2 weeks maintenance resulting in sustained increase in hemoglobin to near normal levels and transfusion independence in all patients upon re-exposure [110]. Sutimlimab was granted breakthrough therapy designation by the US Food and Drug Administration for the treatment of CAD based on these data and a Phase 3 trial recently completed the accrual.

Phosphoinositide 3-kinase (PI3K) inhibitors [111] are in trials as well, and Bruton's tyrosine kinase (BTK) inhibitor ibrutinib has also shown promising results [112]. Figure 2 summarizes current treatment algorithm for cold agglutinin disease.

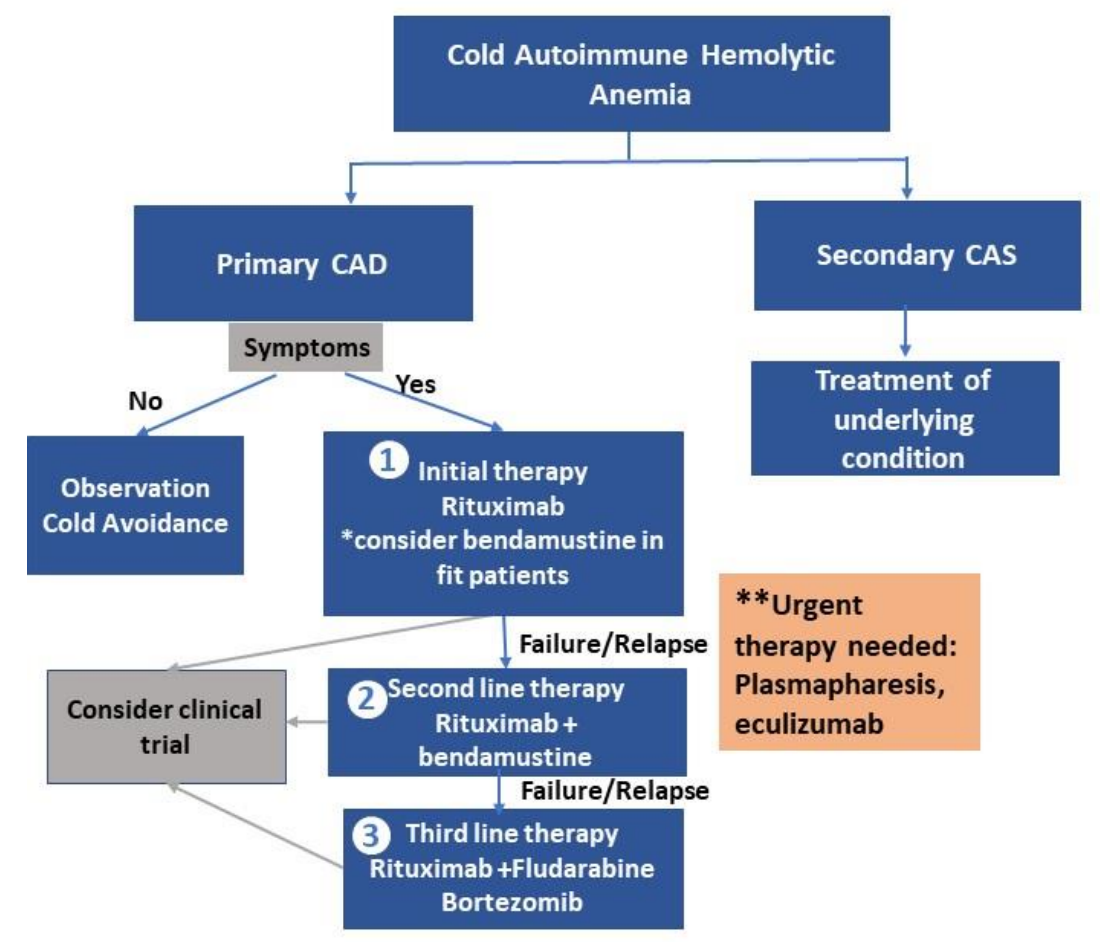

Figure 2. Treatment algorithm for cold agglutinin disease. $\mathrm{CAD}=$ cold agglutinin disease; $\mathrm{CAS}=$ cold agglutinin syndrome; ${ }^{\text {"* }}$ = consider bendamustine in fit patients; ${ }^{\text {"*** }}$ = cases when urgent therapy is needed. 


\section{Rituximab in Primary CAD}

Several retrospective studies reported efficacy of rituximab in cold autoimmune hemolytic anemia, including secondary cold agglutinin syndrome and primary cold agglutinin disease with response rates of $60 \%[43,49]$. In two prospective studies in CAD, single-agent rituximab therapy was associated with overall response rate of $\sim 50 \%[113,114]$. Complete responses were rare, and median duration of response was short at only 6-11 months.

Recognition of presence of an underlying lymphoproliferative disorder in CAD prompted consideration for incorporation of the cytotoxic-lymphoma-directed therapy in rituximab-based therapy. A Norwegian multicenter trial prospectively evaluated a combination of rituximab and fludarabine in 29 patients with CAD. Four 28 -day cycles of oral fludarabine $40 \mathrm{mg} / \mathrm{m}^{2}$ on days 1-5 with standard-dose rituximab $375 \mathrm{mg} / \mathrm{m}^{2}$ were administered. Responses were seen in $76 \%$ of patients with complete response rate of $21 \%$, including patients previously treated with rituximab. Estimated median response duration was greater than 66 months. Toxicity was considerable, with $41 \%$ grade 3-4 hematologic toxicity; 59\% grade 1-3 infections, including recurrent infections; and 10\% herpes zoster reactivation [115]. A 10-year update of this study reported ORR $62 \%$ and CR $38 \%$, with median estimated response duration of 77 months [23]. The rate of late onset second malignancies was $31 \%$, which was numerically higher than all CAD patients and those treated with rituximab/bendamustine combination (13\% and $9 \%$, respectively), although it did not reach statistical significance.

A more recent study investigated combination of rituximab with bendamustine in a prospective, nonrandomized multicenter trial of 45 patients with CAD. Rituximab $375 \mathrm{mg} / \mathrm{m}^{2}$ day 1 and bendamustine $90 \mathrm{mg} / \mathrm{m}^{2}$ days 1 and 2 were administered for 4 28-day cycles. Overall response rate was $71 \%$ with $40 \%$ complete response. Responses were observed in $50 \%$ of cases previously treated with rituximab or rituximab-fludarabine therapy. Acrocyanosis and Raynaud symptoms resolved completely in 50\% of patients and improved in additional 32\%. Grade 3-4 neutropenia was seen in $33 \%$ of patients; $11 \%$ of patients experienced infections, and $29 \%$ of patients required hospitalization for a median of 8 days [116]. In a recent update [23], the authors reported improved response rates with ORR $78 \%$ and CR of $53 \%$, suggesting that responses deepen over time. This was attributed to the prolonged time to response seen in many patients. In patients responding to rituximab-bendamustine, median response duration was not reached after 88 months, and estimated 5-year sustained remission rate was $77 \%$. A combination of rituximab with or without bendamustine is currently recommended in the first line for patients with cold agglutinin disease requiring therapy and in second-line therapy [77].

\section{Rituximab Dose}

Most studies of rituximab in autoimmune hemolytic anemia utilized conventional dose of $375 \mathrm{mg} / \mathrm{m}^{2}$ weekly for 4 weeks used in treatment of lymphoproliferative diseases. Recognition that lymphocyte burden in autoimmune diseases is lower than the tumor mass in lymphoproliferative disorders led to consideration of lower dose rituximab with potential benefit of lower cost and toxicity. Lower doses of rituximab (100 $\mathrm{mg}$ fixed dose) have been studied in various autoimmune settings such as rheumatoid arthritis, vasculitis, thrombotic thrombocytopenic purpura, and immune thrombocytopenic purpura [57,117-119].

In steroid refractory patients with autoimmune cytopenia, low dose rituximab in combination with anti-CD52 monoclonal antibody alemtuzumab produced responses in 100\% of patients and complete response in 58\% [120]. In wAIHA, a retrospective analysis of 64 adults reported response rates of $76.7 \%$ to steroids alone and $100 \%$ to rituximab at $100 \mathrm{mg} /$ week for 4 weeks in combination with high-dose dexamethasone [52].

A prospective Italian multicenter study of low-dose rituximab in warm primary AIHA and CAD demonstrated responses comparable to standard-dose rituximab that were sustained $[61,121]$. In wAIHA, overall response rate was $80-100 \%$ with CR of $60-80 \%$ at 12 months. Response rate in CAD was inferior at around 50\%, with higher relapse rates. Ten-year follow up of this data [122] confirmed the efficacy of lower dose rituximab in primary AIHA. Overall median duration of response was 1 year 
and 3 months, with $62 \%$ of the patients relapsing. In wAIHA, responses deepened overtime, supporting postulated immunomodulatory effect of rituximab. Relapse-free survival (RFS) was significantly longer in wAIHA than in other forms (mixed, atypical forms and CAD) at 64 months vs. 25 months and correlated with the depth of the response. Responses were seen with retreatment with both conventional-dose and low-dose rituximab.

\section{Rituximab Toxicity}

Rituximab has been used extensively in hematologic malignancies, where it has demonstrated a well-established safety profile [123]. Approximately $40 \%$ of patients experience mild to moderate infusion-related reactions, mostly fever and chills, during the first administration of rituximab [87]. The incidence of infusion reactions decreases markedly with subsequent infusions. Rheumatoid arthritis patients receiving rituximab exhibited adverse effect profile similar to patients with lymhoproliferative disorders, but the overall incidence and severity were considerably lower, possibly due to lack of cytokine release associated with lysis of tumor cells. Neutropenia is seen in $2 \%$ patients and hypogammaglobinemia is seen occasionally, but infections are not common [124].

Rare cases of serious viral infections such as John Cunningham polyomavirus (JCV) reactivation leading to progressive multifocal encephalopathy (PML), hepatitis B reactivation, as well as other infections have been reported [124-129]. Majority (65\%) of PML cases are diagnosed in the first 2 years after the first rituximab dose (median time 16 months) and are fatal in 90\% of cases [125]. In a recent review of PML cases reported in a FAERS and EudraVigilance databases, approximate incidence rate of PML ranged from 1.39 to 1.87 per 10,000 exposed patients [126]. Potential synergies, particularly with the purine analog fludarabine, alkylating agent bendamustine, and hematopoietic stem cell transplantation, have been observed, with higher incidence rates of PML in CLL and NonNon-Hodgkin's Lymphoma (NHL) compared to RA patients.

Association of rituximab therapy with hepatitis B viral reactivation was first observed in lymphoma patients [127]. In rheumatoid arthritis, the incidence of reactivation was reported to be $9.1 \%$ among the hepatitis B surface antigen negative/hepatitis B core antibody positive ( $\mathrm{HBsAg}-/ \mathrm{anti}-\mathrm{HBC}+$ ) patients with mean duration of 25.4 months from the first rituximab dose [128]. Pre-treatment screening with hepatitis B serologies and prophylactic antiviral therapy for carriers is recommended in patients who are treated with anti-CD20 therapy [77].

A meta-analysis of 21 studies comprising 154 patients with AIHA treated with rituximab reported toxicities in $14 \%$ patients. Of those, infusion-related side effects, mostly fever and chills, were seen in $42 \%$. The remaining $58 \%$ were more severe, with $2.6 \%$ neutropenias, $12 \%$ severe infections, and Pneumocystis jiroveci pneumonia in one patient [87].

\section{Discussion}

Autoimmune hemolytic anemia is a diverse group of diseases with substantial clinical heterogeneity. Rituximab therapy demonstrated significant efficacy in autoimmune hemolytic anemia in primary as well as secondary forms, and in frontline as well as relapsed settings. In wAIHA, rituximab plays an established role in relapsed disease, providing a safe and effective alternative to splenectomy. Therapy with rituximab in the first line setting is associated with higher response rates and improved relapse-free survival compared to steroids and allows for limited treatment duration. Cost of rituximab therapy is significant compared to glucocorticoid therapy. Front line rituximab therapy can be considered in selected cases where prolonged corticosteroid therapy is not desirable.

In cold agglutinin disease, rituximab alone or in combination with bendamustine is effective in alleviating anemia as well as cold-induced circulatory symptoms and is currently the recommended therapy in the first as well as second-line settings [77]. Responses can take up to 6 weeks, and infectious complications are a concern with chemotherapy-based regimens. Further studies are needed to investigate the role of combination of rituximab with novel B cell directed therapies for potential chemotherapy-free combinations. 
Use of low-fixed-dose rituximab in wAIHA demonstrated comparable efficacy to standard-dose rituximab and can ameliorate cost as well as toxicity considerations. Prospective studies comparing various dose levels are needed. Patients with cold agglutinin disease have higher lymphocyte burden in the setting of clonal lymphoproliferative disorder and derive more benefits from conventional dose rituximab [17].

Although relapses are common, retreatment with rituximab is generally effective in reestablishing remission. Rituximab maintenance therapy has not been prospectively studied in autoimmune hemolytic anemia and is a potential direction for further investigation, particularly in multiple-relapse patients.

Several novel agents targeting various aspects of pathophysiology of autoimmune hemolytic anemia are currently under investigation for wAIHA and CAD, expanding therapeutic options for these uncommon and challenging to treat conditions. Sequencing these therapies and combining them with rituximab are potential challenges to be addressed in future clinical trials.

Author Contributions: I.M. wrote this review. All authors have read and agreed to the published version of the manuscript.

Funding: This research received no external funding.

Conflicts of Interest: The author declares no conflict of interest.

\section{References}

1. Petz, L.D.; Garratty, G. Immune Hemolytic Anemias, 2nd ed.; Churchill Livingstone: Philadelphia, PA, USA, 2004.

2. Lechner, K.; Jager, U. How I treat autoimmune hemolytic anemias in adults. Blood 2010, 116, 1831-1838. [CrossRef] [PubMed]

3. Gehrs, B.C.; Friedberg, R.C. Autoimmune hemolytic anemia. Am. J. Hematol. 2002, 69, 258-271. [CrossRef] [PubMed]

4. Barcellini, W. New Insights in the Pathogenesis of Autoimmune Hemolytic Anemia. Transfus. Med. Hemother. 2015, 42, 287-293. [CrossRef] [PubMed]

5. Sokol, R.J.; Hewitt, S.; Stamps, B.K. Autoimmune haemolysis: An 18-year study of 865 cases referred to a regional transfusion centre. Br. Med. J. (Clin. Res. Ed.) 1981, 282, 2023-2027. [CrossRef]

6. Kamesaki, T.; Kajii, E. A Comprehensive Diagnostic Algorithm for Direct Antiglobulin Test-Negative Autoimmune Hemolytic Anemia Reveals the Relative Ratio of Three Mechanisms in a Single Laboratory. Acta Haematol. 2018, 140, 10-17. [CrossRef]

7. Kalfa, T.A. Warm antibody autoimmune hemolytic anemia. Hematology 2016, 2016, 690-697. [CrossRef]

8. Shi, J.; Rose, E.L.; Singh, A.; Hussain, S.; Stagliano, N.E.; Parry, G.C.; Panicker, S. TNT003, an inhibitor of the serine protease C1s, prevents complement activation induced by cold agglutinins. Blood 2014, 123, 4015-4022. [CrossRef]

9. Shanbhag, S.; Spivak, J. Paroxysmal cold hemoglobinuria. Hematol. Oncol. Clin. N. Am. 2015, $29,473-478$. [CrossRef]

10. Berentsen, S.; Hill, A.; Hill, Q.A.; Tvedt, T.H.A.; Michel, M. Novel insights into the treatment of complement-mediated hemolytic anemias. Ther. Adv. Hematol. 2019, 10. [CrossRef]

11. Valent, P.; Lechner, K. Diagnosis and treatment of autoimmune haemolytic anaemias in adults: A clinical review. Wien. Klin. Wochenschr. 2008, 120, 136-151. [CrossRef]

12. Wang, M.; Wang, W.; Abeywardane, A.; Adikarama, M.; McLornan, D.; Raj, K.; de Lavallade, H.; Devereux, S.; Mufti, G.J.; Pagliuca, A.; et al. Autoimmune hemolytic anemia after allogeneic hematopoietic stem cell transplantation: Analysis of 533 adult patients who underwent transplantation at King's College Hospital. Biol. Blood Marrow Transplant. 2015, 21, 60-66. [CrossRef] [PubMed]

13. González-Vicent, M.; Sanz, J.; Fuster, J.L.; Cid, J.; de Heredia, C.D.; Morillo, D.; Fernández, J.M.; Pascual, A.; Badell, I.; Serrano, D.; et al. Autoimmune hemolytic anemia (AIHA) following allogeneic hematopoietic stem cell transplantation (HSCT): A retrospective analysis and a proposal of treatment on behalf of the Grupo Español De Trasplante de Medula Osea en Niños (GETMON) and the Grupo Español de Trasplante Hematopoyetico (GETH). Transfus. Med. Rev. 2018, 32, 179-185. [CrossRef] 
14. Barcellini, W.; Fattizzo, B.; Zaninoni, A. Management of refractory autoimmune hemolytic anemia after allogeneic hematopoietic stem cell transplantation: Current perspectives. J. Blood Med. 2019, 10, $265-278$. [CrossRef] [PubMed]

15. Tanios, G.E.; Doley, P.B.; Munker, R. Autoimmune hemolytic anemia associated with the use of immune checkpoint inhibitors for cancer: 68 cases from the Food and Drug Administration database and review. Eur. J. Haematol. 2019, 102, 157-162. [CrossRef]

16. Atiq, O.; Atiq, S.O.; Atiq, Z.O.; Patel, V.; Atiq, M.O.; Atiq, O.T. Pembrolizumab-Induced Cold Agglutinin Disease. Am. J. Case Rep. 2020, 21, e924283. [CrossRef]

17. Barcellini, W.; Fattizzo, B.; Zaninoni, A.; Radice, T.; Nichele, I.; Di Bona, E.; Lunghi, M.; Tassinari, C.; Alfinito, F.; Ferrari, A.; et al. Clinical heterogeneity and predictors of outcome in primary autoimmune hemolytic anemia: A GIMEMA study of 308 patients. Blood 2014, 124, 2930-2936. [CrossRef]

18. Fattizzo, B.; Michel, M.; Zaninoni, A.; Giannotta, J.; Guillet, S.; Frederiksen, H.; Vos, J.M.I.; Mauro, F.R.; Jilma, B.; Patriarca, A.; et al. Efficacy of recombinant erythropoietin in autoimmune haemolytic anaemia: A multicentre international study. Haematologica 2020. [CrossRef]

19. Audia, S.; Bach, B.; Samson, M.; Lakomy, D.; Bour, J.B.; Burlet, B.; Guy, J.; Duvillard, L.; Branger, M.; Leguy-Seguin, V.; et al. Venous thromboembolic events during warm autoimmune hemolytic anemia. PLoS ONE 2018, 13, e0207218. [CrossRef]

20. Broome, C.M.; Cunningham, J.M.; Mullins, M.; Jiang, X.; Bylsma, L.C.; Fryzek, J.P.; Rosenthal, A. Increased risk of thrombotic events in cold agglutinin disease: A 10-year retrospective analysis. Res. Pract. Thromb. Haemost. 2020, 4, 628-635. [CrossRef]

21. Bylsma, L.C.; Gulbech Ording, A.; Rosenthal, A.; Öztürk, B.; Fryzek, J.P.; Arias, J.M.; Röth, A.; Berentsen, S. Occurrence, thromboembolic risk, and mortality in Danish patients with cold agglutinin disease. Blood Adv. 2019, 3, 2980-2985. [CrossRef]

22. Berentsen, S.; Ulvestad, E.; Langholm, R.; Beiske, K.; Hjorth-Hansen, H.; Ghanima, W.; Sørbø, J.H.; Tjønnfjord, G.E. Primary chronic cold agglutinin disease: A population based clinical study of 86 patients. Haematologica 2006, 91, 460-466. [PubMed]

23. Berentsen, S.; Barcellini, W.; D’Sa, S.; Randen, U.; Tvedt, T.H.A.; Fattizzo, B.; Haukås, E.; Kell, M.; Brudevold, R.; Dahm, A.E.A.; et al. Cold agglutinin disease revisited: A multinational, observational study of 232 patients. Blood 2020, 136, 480-488. [CrossRef] [PubMed]

24. Dierickx, D.; Kentos, A.; Delannoy, A. The role of rituximab in adults with warm antibody autoimmune hemolytic anemia. Blood 2015, 125, 3223-3229. [CrossRef] [PubMed]

25. Ahmad, E.; Elgohary, T.; Ibrahim, H. Naturally occurring regulatory T cells and interleukins 10 and 12 in the pathogenesis of idiopathic warm autoimmune hemolytic anemia. J. Investig. Allergol. Clin. Immunol. 2011, 21, 297-304.

26. Howie, H.L.; Hudson, K.E. Murine models of autoimmune hemolytic anemia. Curr. Opin. Hematol. 2018, 25, 473-481. [CrossRef]

27. Leung, S.; Liu, X.; Fang, L.; Chen, X.; Guo, T.; Zhang, J. The cytokine milieu in the interplay of pathogenic Th1/Th17 cells and regulatory T cells in autoimmune disease. Cell. Mol. Immunol. 2010, 7, 182-189. [CrossRef]

28. Barcellini, W.; Clerici, G.; Montesano, R.; Taioli, E.; Morelati, F.; Rebulla, P.; Zanella, A. In vitro quantification of anti-red blood cell antibody production in idiopathic autoimmune haemolytic anaemia: Effect of mitogen and cytokine stimulation. Br. J. Haematol. 2000, 111, 452-460. [CrossRef]

29. Noack, M.; Miossec, P. Th17 and regulatory T cell balance in autoimmune and inflammatory diseases. Autoimmun. Rev. 2014, 13, 668-677. [CrossRef]

30. Gao, Y.; Jin, H.; Nan, D.; Yu, W.; Zhang, J.; Yang, Y.; Hou, R.; Qin, R.; Hao, H.; Sun, Y.; et al. The Role of T Follicular Helper Cells and T Follicular Regulatory Cells in the Pathogenesis of Autoimmune Hemolytic Anemia. Sci. Rep. 2019, 9, 1-11. [CrossRef]

31. Randen, U.; Trøen, G.; Tierens, A.; Steen, C.; Warsame, A.; Beiske, K.; Tjønnfjord, G.E.; Berentsen, S.; Delabie, J. Primary cold agglutinin-associated lymphoproliferative disease: A B-cell lymphoma of the bone marrow distinct from lymphoplasmacytic lymphoma. Haematologica 2014, 99, 497-504. [CrossRef]

32. de Tute, R.; Rawstron, A.; Evans, P.; Owen, R. Cold agglutinin disease is a phenotypically distinct clonal B-cell disorder. Clin. Lymphoma Myeloma Leuk. 2015, 15 (Suppl. 3), e184. [CrossRef] 
33. Małecka, A.; Trøen, G.; Tierens, A.; Østlie, I.; Małecki, J.; Randen, U.; Berentsen, S.; Tjønnfjord, G.E.; Delabie, J.M. Immunoglobulin heavy and light chain gene features are correlated with primary cold agglutinin disease onset and activity. Haematologica 2016, 101, e361-e364. [CrossRef] [PubMed]

34. Małecka, A.; Delabie, J.; Østlie, I.; Tierens, A.; Randen, U.; Berentsen, S.; Tjønnfjord, G.E.; Trøen, G. Cold agglutinin-associated B-cell lymphoproliferative disease shows highly recurrent gains of chromosome 3 and 12 or 18. Blood Adv. 2020, 4, 993-996. [CrossRef] [PubMed]

35. Małecka, A.; Trøen, G.; Tierens, A.; Østlie, I.; Małecki, J.; Randen, U.; Wang, J.; Berentsen, S.; Tjønnfjord, G.E.; Delabie, J.M.A. Frequent somatic mutations of KMT2D (MLL2) and CARD11 genes in primary cold agglutinin disease. Br. J. Haematol. 2018, 183, 838-842. [CrossRef]

36. Harboe, M.; van Furth, R.; Schubothe, H.; Lind, K.; Evans, R.S. Exclusive occurrence of K chains in isolated cold haemagglutinins. Scand. J. Haematol. 1965, 2, 259-266. [CrossRef]

37. Ulvestad, E.; Berentsen, S.; Bø, K.; Shammas, F.V. Clinical immunology of chronic cold agglutinin disease. Eur. J. Haematol. 1999, 63, 259-266. [CrossRef]

38. Berentsen, S. Cold agglutinin disease. Hematol. Am. Soc. Hematol. Educ. Program. 2016, 2016, $226-231$. [CrossRef]

39. Smith, M.R. Rituximab (monoclonal anti-CD20 antibody): Mechanisms of action and resistance. Oncogene 2003, 22, 7359-7368. [CrossRef]

40. Reff, M.E.; Carner, K.; Chambers, K.S.; Chinn, P.C.; Leonard, J.E.; Raab, R.; Newman, R.A.; Hanna, N.; Anderson, D.R. Depletion of B cells in vivo by a chimeric mouse human monoclonal antibody to CD20. Blood 1994, 83, 435-445. [CrossRef]

41. Cohen, S.B.; Emery, P.; Greenwald, M.W.; Dougados, M.; Furie, R.A.; Genovese, M.C.; Keystone, E.C.; Loveless, J.E.; Burmester, G.R.; Cravets, M.W.; et al. Rituximab for rheumatoid arthritis refractory to anti-tumor necrosis factor therapy: Results of a multicenter, randomized, double-blind, placebo-controlled, phase III trial evaluating primary efficacy and safety at twenty-four weeks. Arthritis Rheum. 2006, 54, 2793-2806. [CrossRef]

42. Haraoui, B.; Bokarewa, M.; Kallmeyer, I.; Bykerk, V.P.; RESET Investigators. Safety and effectiveness of rituximab in patients with rheumatoid arthritis following an inadequate response to 1 prior tumor necrosis factor inhibitor: The RESET Trial. J. Rheumatol. 2011, 38, 2548-2556. [CrossRef] [PubMed]

43. Dierickx, D.; Verhoef, G.; Van Hoof, A.; Mineur, P.; Roest, A.; Triffet, A.; Kentos, A.; Pierre, P.; Boulet, D.; Bries, G.; et al. Rituximab in auto-immune haemolytic anaemia and immune thrombocytopenic purpura: A Belgian retrospective multicentric study. J. Intern. Med. 2009, 266, 484-491. [CrossRef] [PubMed]

44. Garvey, B. Rituximab in the treatment of autoimmune haematological disorders. Br. J. Haematol. 2008, 141, 149-169. [CrossRef] [PubMed]

45. Barcellini, W.; Zanella, A. Rituximab therapy for autoimmune haematological diseases. Eur. J. Intern. Med. 2011, 22, 220-229. [CrossRef]

46. Narat, S.; Gandla, J.; Hoffbrand, A.V.; Hughes, R.G.; Mehta, A.B. Rituximab in the treatment of refractory autoimmune cytopenias in adults. Haematologica 2005, 90, 1273-1274.

47. D'Arena, G.; Califano, C.; Annunziata, M.; Tartarone, A.; Capalbo, S.; Villani, O.; Amendola, G.; Pietrantuono, G.; Ferrara, F.; Pinto, A.; et al. Rituximab for warm-type idiopathic autoimmune hemolytic anemia: A retrospective study of 11 adult patients. Eur. J. Haematol. 2007, 79, 53-58. [CrossRef]

48. Bussone, G.; Ribeiro, E.; Dechartres, A.; Viallard, J.F.; Bonnotte, B.; Fain, O.; Godeau, B.; Michel, M. Efficacy and safety of rituximab in adults' warm antibody autoimmune haemolytic anemia: Retrospective analysis of 27 cases. Am. J. Hematol. 2009, 84, 153-157. [CrossRef]

49. Peñalver, F.J.; Alvarez-Larrán, A.; Díez-Martin, J.L.; Gallur, L.; Jarque, I.; Caballero, D.; Díaz-Mediavilla, J.; Bustelos, R.; Fernández-Aceñero, M.J.; Cabrera, J.R.; et al. Rituximab is an effective and safe therapeutic alternative in adults with refractory and severe autoimmune hemolytic anemia. Ann. Hematol. 2010, 89, 1073-1080. [CrossRef]

50. Roumier, M.; Loustau, V.; Guillaud, C.; Languille, L.; Mahevas, M.; Khellaf, M.; Limal, N.; Noizat-Pirenne, F.; Godeau, B.; Michel, M. Characteristics and outcome of warm autoimmune hemolytic anemia in adults: New insights based on a single-center experience with 60 patients. Am. J. Hematol. 2014, 89, E150-E155. [CrossRef] 
51. Hauswirth, A.W.; Skrabs, C.; Schützinger, C.; Gaiger, A.; Lechner, K.; Jäger, U. Autoimmune hemolytic anemias, Evans' syndromes, and pure red cell aplasia in non-Hodgkin lymphomas. Leuk. Lymphoma 2007, 48, 1139-1149. [CrossRef]

52. Jaime-Pérez, J.C.; Aguilar-Calderón, P.; Salazar-Cavazos, L.; Gómez-De León, A.; Gómez-Almaguer, D. Treatment of autoimmune hemolytic anemia: Real world data from a reference center in Mexico. Blood Res. 2019, 54, 131-136. [CrossRef] [PubMed]

53. D'Arena, G.; Laurenti, L.; Capalbo, S.; D'Arco, A.M.; De Filippi, R.; Marcacci, G.; Di Renzo, N.; Storti, S.; Califano, C.; Vigliotti, M.L.; et al. Rituximab therapy for chronic lymphocytic leukemia-associated autoimmune hemolytic anemia. Am. J. Hematol. 2006, 81, 598-602. [CrossRef] [PubMed]

54. Maloney, D.G.; Liles, T.M.; Czerwinski, D.K.; Waldichuk, C.; Rosenberg, J.; Grillo-Lopez, A.; Levy, R. Phase I clinical trial using escalating single-dose infusion of chimeric anti-CD20 monoclonal antibody (IDEC-C2B8) in patients with recurrent B-cell lymphoma. Blood 1994, 84, 2457-2466. [CrossRef] [PubMed]

55. Tamimoto, Y.; Horiuchi, T.; Tsukamoto, H.; Otsuka, J.; Mitoma, H.; Kimoto, Y.; Nakashima, H.; Muta, K.; Abe, Y.; Kiyohara, C.; et al. A dose-escalation study of rituximab for treatment of systemic lupus erythematosus and Evans' syndrome: Immunological analysis of B cells, T cells and cytokines. Rheumatology 2008, 47, 821-827. [CrossRef]

56. Stasi, R. Rituximab in autoimmune hematologic diseases: Not just a matter of B cells. Semin. Hematol. 2010, 47, 170-179. [CrossRef]

57. Li, Z.; Mou, W.; Lu, G.; Cao, J.; He, X.; Pan, X.; Xu, K. Low-dose rituximab combined with short-term glucocorticoids up-regulates Treg cell levels in patients with immune thrombocytopenia. Int. J. Hematol. 2011, 93, 91-98. [CrossRef]

58. Stasi, R.; Del Poeta, G.; Stipa, E.; Evangelista, M.L.; Trawinska, M.M.; Cooper, N.; Amadori, S. Response to B-cell depleting therapy with rituximab reverts the abnormalities of T-cell subsets in patients with idiopathic thrombocytopenic purpura. Blood 2007, 110, 2924-2930. [CrossRef]

59. Stasi, R.; Cooper, N.; Del Poeta, G.; Stipa, E.; Laura Evangelista, M.; Abruzzese, E.; Amadori, S. Analysis of regulatory $\mathrm{T}$-cell changes in patients with idiopathic thrombocytopenic purpura receiving $\mathrm{B}$ cell-depleting therapy with rituximab. Blood 2008, 112, 1147-1150. [CrossRef]

60. Bhatia, D.; Sinha, A.; Hari, P.; Sopory, S.; Saini, S.; Puraswani, M.; Saini, H.; Mitra, D.K.; Bagga, A. Rituximab modulates T- and B-lymphocyte subsets and urinary CD80 excretion in patients with steroid-dependent nephrotic syndrome. Pediatr. Res. 2018, 84, 520-526. [CrossRef]

61. Barcellini, W.; Zaja, F.; Zaninoni, A.; Imperiali, F.G.; Battista, M.L.; Di Bona, E.; Fattizzo, B.; Consonni, D.; Cortelezzi, A.; Fanin, R.; et al. Low-dose rituximab in adult patients with idiopathic autoimmune hemolytic anemia: Clinical efficacy and biologic studies. Blood 2012, 119, 3691-3697. [CrossRef]

62. Zanella, A.; Barcellini, W. Treatment of autoimmune hemolytic anemias. Haematologica 2014, 99, 1547-1554. [CrossRef] [PubMed]

63. Allgood, J.W.; Chaplin, H., Jr. Idiopathic acquired autoimmune hemolytic anemia. A review of forty-seven cases treated from 1955 through 1965. Am. J. Med. 1967, 43, 254-273. [CrossRef]

64. Kulpa, J.; Skrabs, C.; Simanek, R.; Valent, P.; Panzer, S.; Lechner, K.; Sillaber, C.; Jäger, U. Probability of remaining in unsustained complete remission after steroid therapy withdrawal in patients with primary warm-antibody reactive autoimmune hemolytic anemia. Wien. Klin. Wochenschr. 2016, 128, $234-237$. [CrossRef] [PubMed]

65. Coon, W.W. Splenectomy in the treatment of hemolytic anemia. Arch. Surg. 1985, 120, 625-628. [CrossRef] [PubMed]

66. Patel, N.Y.; Chilsen, A.M.; Mathiason, M.A.; Kallies, K.J.; Bottner, W.A. Outcomes and complications after splenectomy for hematologic disorders. Am. J. Surg. 2012, 204, 1014-1019. [CrossRef] [PubMed]

67. Akpek, G.; McAneny, D.; Weintraub, L. Comparative response to splenectomy in Coombs-positive autoimmune hemolytic anemia with or without associated disease. Am. J. Hematol. 1999, 61, 98-102. [CrossRef]

68. Balagué, C.; Targarona, E.M.; Cerdán, G.; Novell, J.; Montero, O.; Bendahan, G.; García, A.; Pey, A.; Vela, S.; Diaz, M.; et al. Long-term outcome after laparoscopic splenectomy related to hematologic diagnosis. Surg. Endosc. 2004, 18, 1283-1287. [CrossRef]

69. Bisharat, N.; Omari, H.; Lavi, I.; Raz, R. Risk of infection and death among post-splenectomy patients. J. Infect. 2001, 43, 182-186. [CrossRef] 
70. Thomsen, R.W.; Schoonen, W.M.; Farkas, D.K.; Riis, A.; Jacobsen, J.; Fryzek, J.P.; Sørensen, H.T. Risk for hospital contact with infection in patients with splenectomy: A population-based cohort study. Ann. Intern. Med. 2009, 151, 546-555. [CrossRef]

71. Thomsen, R.W.; Schoonen, W.M.; Farkas, D.K.; Riis, A.; Fryzek, J.P.; Sørensen, H.T. Risk of venous thromboembolism in splenectomized patients compared with the general population and appendectomized patients: A 10-year nationwide cohort study. J. Thromb. Haemost. 2010, 8, 1413-1416. [CrossRef]

72. Pepke-Zaba, J.; Delcroix, M.; Lang, I.; Mayer, E.; Jansa, P.; Ambroz, D.; Treacy, C.; D’Armini, A.M.; Morsolini, M.; Snijder, R.; et al. Chronic thromboembolic pulmonary hypertension (CTEPH): Results from an international prospective registry. Circulation 2011, 124, 1973-1981. [CrossRef] [PubMed]

73. Barcellini, W.; Fattizzo, B.; Zaninoni, A. Current and emerging treatment options for autoimmune hemolytic anemia. Expert Rev. Clin. Immunol. 2018, 14, 857-872. [CrossRef] [PubMed]

74. Hill, Q.A.; Stamps, R.; Massey, E.; Grainger, J.D.; Provan, D.; Hill, A.; British Society for Haematology. The diagnosis and management of primary autoimmune haemolytic anaemia. Br. J. Haematol. 2017, 176, 395-411. [CrossRef] [PubMed]

75. Hill, Q.A.; Stamps, R.; Massey, E.; Grainger, J.D.; Provan, D.; Hill, A.; British Society for Haematology Guidelines. Guidelines on the management of drug-induced immune and secondary autoimmune, haemolytic anaemia. Br. J. Haematol. 2017, 177, 208-220. [CrossRef] [PubMed]

76. Go, R.S.; Winters, J.L.; Kay, N.E. How I treat autoimmune hemolytic anemia. Blood 2017, 129, $2971-2979$. [CrossRef] [PubMed]

77. Jäger, U.; Barcellini, W.; Broome, C.M.; Gertz, M.A.; Hill, A.; Hill, Q.A.; Jilma, B.; Kuter, D.J.; Michel, M.; Montillo, M.; et al. Diagnosis and treatment of autoimmune hemolytic anemia in adults: Recommendations from the First International Consensus Meeting. Blood Rev. 2020, 41, 100648. [CrossRef]

78. Serrano, J. Autoimmune hemolytic anemia. Review of 200 cases studied in a period of 20 years (1970-1989). Sangre 1992, 37, 265-274.

79. Ahn, Y.S. Efficacy of danazol in hematologic disorders. Acta Haematol. 1990, 84, 122-129. [CrossRef]

80. A Safety and Efficacy Study of R935788 in the Treatment of Warm Antibody Autoimmune Hemolytic Anemia (AIHA) (SOAR). Available online: https://www.clinicaltrials.gov/ct2/show/NCT02612558 (accessed on 19 November 2020).

81. Momenta Pharmaceuticals. Efficacy and Safety of M281 in Adults with Warm Autoimmune Hemolytic Anemia: A Multicenter, Randomized, Double-blind, Placebo-controlled Study. Available online: https: //www.clinicaltrials.gov/ct2/show/NCT04119050 (accessed on 19 November 2020).

82. Immunovant Sciences GmbH. To Assess the Efficacy and Safety of RVT-1401 in the Treatment of Warm Autoimmune Hemolytic Anemia (ASCEND-WAIHA). (ASCEND-WAIHA). Available online: https://www. clinicaltrials.gov/ct2/show/NCT04253236 (accessed on 19 November 2020).

83. Ibrutinib in Steroid Refractory Autoimmune Hemolytic Anemia (ISRAEL). Available online: https://www. clinicaltrials.gov/ct2/show/NCT03827603 (accessed on 19 November 2020).

84. A Phase II, Single-Center, Open-label Trial to Determine the Safety and Efficacy of Ibrutinib in Refractory/Relapsed Autoimmune Hemolytic Anemia. Available online: https://www.clinicaltrials.gov/ct2/ show/NCT04398459 (accessed on 19 November 2020).

85. Zecca, M.; Nobili, B.; Ramenghi, U.; Perrotta, S.; Amendola, G.; Rosito, P.; Jankovic, M.; Pierani, P.; De Stefano, P.; Bonora, M.R.; et al. Rituximab for the treatment of refractory autoimmune hemolytic anemia in children. Blood 2003, 101, 3857-3861. [CrossRef]

86. Maung, S.W.; Leahy, M.; O’Leary, H.M.; Khan, I.; Cahill, M.R.; Gilligan, O.; Murphy, P.; McPherson, S.; Jackson, F.; Hennessy, B.; et al. A multi-centre retrospective study of rituximab use in the treatment of relapsed or resistant warm autoimmune haemolytic anaemia. Br. J. Haematol. 2013, 163, 118-122. [CrossRef]

87. Reynaud, Q.; Durieu, I.; Dutertre, M.; Ledochowski, S.; Durupt, S.; Michallet, A.S.; Durand, D.V.; Lega, J.C. Efficacy and safety of rituximab in auto-immune hemolytic anemia: A meta-analysis of 21 studies. Autoimmun. Rev. 2015, 14, 304-313. [CrossRef]

88. Birgens, H.; Frederiksen, H.; Hasselbalch, H.C.; Rasmussen, I.H.; Nielsen, O.J.; Kjeldsen, L.; Larsen, H.; Mourits-Andersen, T.; Plesner, T.; Rønnov-Jessen, D.; et al. A phase III randomized trial comparing glucocorticoid monotherapy versus glucocorticoid and rituximab in patients with autoimmune haemolytic anaemia. Br. J. Haematol. 2013, 163, 393-399. [CrossRef] 
89. Michel, M.; Terriou, L.; Roudot-Thoraval, F.; Hamidou, M.; Ebbo, M.; Le Guenno, G.; Galicier, L.; Audia, S.; Royer, B.; Morin, A.S.; et al. A randomized and double-blind controlled trial evaluating the safety and efficacy of rituximab for warm auto-immune hemolytic anemia in adults (the RAIHA study). Am. J. Hematol. 2017, 92, 23-27. [CrossRef]

90. Rossignol, J.; Michallet, A.S.; Oberic, L.; Picard, M.; Garon, A.; Willekens, C.; Dulery, R.; Leleu, X.; Cazin, B.; Ysebaert, L. Rituximab-cyclophosphamide-dexamethasone combination in the management of autoimmune cytopenias associated with chronic lymphocytic leukemia. Leukemia 2011, 25, 473-478. [CrossRef]

91. Kaufman, M.; Limaye, S.A.; Driscoll, N.; Johnson, C.; Caramanica, A.; Lebowicz, Y.; Patel, D.; Kohn, N.; Rai, K. A combination of rituximab, cyclophosphamide and dexamethasone effectively treats immune cytopenias of chronic lymphocytic leukemia. Leuk. Lymphoma 2009, 50, 892-899. [CrossRef]

92. Bocian, H.; Piatek, C.; Liebman, H.A.; O'Connell, C.L.; Weitz, I.C.; Johnson, C.S. Combination treatment of rituximab, cyclophosphamide, and dexamethasone for warm autoimmune hemolytic anemia. Blood 2016, 128, 4802. [CrossRef]

93. Piatek, C.I.; Bocian, H.; Algaze, S.; Weitz, I.C.; O'Connell, C.; Liebman, H.A. A Retrospective Study of the Combination of Rituximab, Cyclophosphamide and Dexamethasone for the Treatment of Relapsed/Refractory Warm Antibody Autoimmune Hemolytic Anemia. Acta Haematol. 2020, 143, 244-249. [CrossRef]

94. Bowen, D.A.; Call, T.G.; Shanafelt, T.D.; Kay, N.E.; Schwager, S.M.; Reinalda, M.S.; Rabe, K.G.; Slager, S.L.; Zent, C.S. Treatment of autoimmune cytopenia complicating progressive chronic lymphocytic leukemia/small lymphocytic lymphoma with rituximab, cyclophosphamide, vincristine, and prednisone. Leuk. Lymphoma 2010, 51, 620-627. [CrossRef]

95. Quinquenel, A.; Willekens, C.; Dupuis, J.; Royer, B.; Ysebaert, L.; De Guibert, S.; Michallet, A.S.; Feugier, P.; Guieze, R.; Levy, V.; et al. Bendamustine and rituximab combination in the management of chronic lymphocytic leukemia-associated autoimmune hemolytic anemia: A multicentric retrospective study of the French CLL intergroup (GCFLLC/MW and GOELAMS). Am. J. Hematol. 2015, 90, 204-207. [CrossRef]

96. Serris, A.; Amoura, Z.; Canouï-Poitrine, F.; Terrier, B.; Hachulla, E.; Costedoat-Chalumeau, N.; Papo, T.; Lambotte, O.; Saadoun, D.; Blanche, P.; et al. Efficacy and safety of rituximab for systemic lupus erythematosus-associated immune cytopenias: A multicenter retrospective cohort study of 71 adults. Am. J. Hematol. 2018, 93, 424-429. [CrossRef]

97. Gobert, D.; Bussel, J.B.; Cunningham-Rundles, C.; Galicier, L.; Dechartres, A.; Berezne, A.; Bonnotte, B.; DeRevel, T.; Auzary, C.; Jaussaud, R.; et al. Efficacy and safety of rituximab in common variable immunodeficiency-associated immune cytopenias: A retrospective multicentre study on 33 patients. Br. J. Haematol. 2011, 155, 498-508. [CrossRef] [PubMed]

98. Sanz, J.; Arango, M.; Carpio, N.; Montesinos, P.; Moscardó, F.; Martín, G.; López, F.; Jarque, I.; Lorenzo, I.; De La Rubia, J.; et al. Autoimmune cytopenias after umbilical cord blood transplantation in adults with hematological malignancies: A single-center experience. Bone Marrow Transplant. 2014. [CrossRef] [PubMed]

99. Faraci, M.; Zecca, M.; Pillon, M.; Rovelli, A.; Menconi, M.C.; Ripaldi, M.; Fagioli, F.; Rabusin, M.; Ziino, O.; Lanino, E.; et al. Autoimmune hematological diseases after allogeneic hematopoietic stem cell transplantation in children: An Italian multicenter experience. Biol. Blood Marrow Transplant. 2014, 20, 272-278. [CrossRef] [PubMed]

100. Schreiber, A.D.; Herskovitz, B.S.; Goldwein, M. Low-titer cold-hemagglutinin disease. Mechanism of hemolysis and response to corticosteroids. N. Engl. J. Med. 1977, 296, 1490-1494. [CrossRef]

101. Hippe, E.; Jensen, K.B.; Olesen, H.; Lind, K.; Thomsen, P.E. Chlorambucil treatment of patients with cold agglutinin syndrome. Blood 1970, 35, 68-72. [CrossRef] [PubMed]

102. Berentsen, S. New Insights in the Pathogenesis and Therapy of Cold Agglutinin-Mediated Autoimmune Hemolytic Anemia. Front. Immunol. 2020, 11, 590. [CrossRef]

103. Rossi, G.; Gramegna, D.; Paoloni, F.; Fattizzo, B.; Binda, F.; D’Adda, M.; Farina, M.; Lucchini, E.; Mauro, F.R.; Salvi, F.; et al. Short course of bortezomib in anemic patients with relapsed cold agglutinin disease: A phase 2 prospective GIMEMA study. Blood 2018, 132, 547-550. [CrossRef]

104. Röth, A.; Bommer, M.; Hüttmann, A.; Herich-Terhürne, D.; Kuklik, N.; Rekowski, J.; Lenz, V.; Schrezenmeier, H.; Dührsen, U. Eculizumab in cold agglutinin disease (DECADE): An open-label, prospective, bicentric, nonrandomized phase 2 trial. Blood Adv. 2018, 2, 2543-2549. [CrossRef] 
105. Grossi, F.; Shum, M.K.; Gertz, M.A.; Roman, E.; Deschatelets, P.; Hamdani, M.; Stout, F.; Francois, C.G. Inhibition of C3 with APL-2 results in normalisation of markers of intravascular and extravascular hemolysis in patients with autoimmune hemolytic anemia (AIHA). Blood 2018, 132 (Suppl. 1), 3623. [CrossRef]

106. Röth, A.; Barcellini, W.; D’Sa, S.; Miyakawa, Y.; Broome, C.M.; Michel, M.; Kuter, D.J.; Jilma, B.; Tvedt, T.H.A.; Lin, S.; et al. Inhibition of Complement C1s with Sutimlimab in Patients with Cold Agglutinin Disease (CAD): Results from the Phase 3 Cardinal Study. Blood 2019, 134 (Suppl. 2), LBA-2. [CrossRef]

107. A Study to Assess the Efficacy and Safety of BIVV009 (Sutimlimab) in Participants With Primary Cold Agglutinin Disease Without A Recent History of Blood Transfusion (Cadenza). Available online: https: //www.clinicaltrials.gov/ct2/show/NCT03347422 (accessed on 19 November 2020).

108. A Study to Assess the Efficacy and Safety of BIVV009 (Sutimlimab) in Participants With Primary Cold Agglutinin Disease Who Have a Recent History of Blood Transfusion (Cardinal Study). Available online: https://www.clinicaltrials.gov/ct2/show/NCT03347396 (accessed on 19 November 2020).

109. Jäger, U.; D’Sa, S.; Schörgenhofer, C.; Bartko, J.; Derhaschnig, U.; Sillaber, C.; Jilma-Stohlawetz, P.; Fillitz, M.; Schenk, T.; Patou, G.; et al. Inhibition of complement C1s improves severe hemolytic anemia in cold agglutinin disease: A first-in-human trial. Blood 2019, 133, 893-901. [CrossRef] [PubMed]

110. Gelbenegger, G.; Schoergenhofer, C.; Derhaschnig, U.; Buchtele, N.; Sillaber, C.; Fillitz, M.; Schenk, T.M.; D'Sa, S.; Cartwright, R.; Gilbert, J.C.; et al. Inhibition of complement C1s in patients with cold agglutinin disease: Lessons learned from a named patient program. Blood Adv. 2020, 4, 997-1005. [CrossRef] [PubMed]

111. A Phase 2, Open-Label Study of INCB050465 in Participants with Autoimmune Hemolytic Anemia. Available online: https://www.clinicaltrials.gov/ct2/show/NCT03538041 (accessed on 19 November 2020).

112. Jalink, M.; Berentsen, S.; Castillo, J.J.; Treon, S.; Fattizzo, B.; Cassin, R.; De Haas, M.; Patriarca, A.; D'Sa, S.; Josephine, M.I.V. Effective Treatment of Cold Agglutinin Disease/Cold Agglutinin Syndrome with Ibrutinib: An International Case Series. 62nd Annual Meeting of the American Society of Hematology 2020. Abstract 1678. Available online: https://ash.confex.com/ash/2020/webprogram/Paper139131.html (accessed on 19 November 2020).

113. Schöllkopf, C.; Kjeldsen, L.; Bjerrum, O.W.; Mourits-Andersen, H.T.; Nielsen, J.L.; Christensen, B.E.; Jensen, B.A.; Pedersen, B.B.; Taaning, E.B.; Klausen, T.W.; et al. Rituximab in chronic cold agglutinin disease: A prospective study of 20 patients. Leuk. Lymphoma 2006, 47, 253-260. [CrossRef] [PubMed]

114. Berentsen, S.; Ulvestad, E.; Gjertsen, B.T.; Hjorth-Hansen, H.; Langholm, R.; Knutsen, H.; Ghanima, W.; Shammas, F.V.; Tjønnfjord, G.E. Rituximab for primary chronic cold agglutinin disease: A prospective study of 37 courses of therapy in 27 patients. Blood 2004, 103, 2925-2928. [CrossRef]

115. Berentsen, S.; Randen, U.; Vågan, A.M.; Hjorth-Hansen,H.; Vik, A.; Dalgaard, J.; Jacobsen, E.M.; Thoresen, A.S.; Beiske, K.; Tjønnfjord, G.E. High response rate and durable remissions following fludarabine and rituximab combination therapy for chronic cold agglutinin disease. Blood 2010, 116, 3180-3184. [CrossRef]

116. Berentsen, S.; Randen, U.; Oksman, M.; Birgens, H.; Tvedt, T.H.A.; Dalgaard, J.; Galteland, E.; Haukås, E.; Brudevold, R.; Sørbø, J.H.; et al. Bendamustine plus rituximab for chronic cold agglutinin disease: Results of a Nordic prospective multicenter trial. Blood 2017, 130, 537-541. [CrossRef]

117. Provan, D.; Butler, T.; Evangelista, M.L.; Amadori, S.; Newland, A.C.; Stasi, R. Activity and safety profile of low-dose rituximab for the treatment of autoimmune cytopenias in adults. Haematologica 2007, 92, 1695-1698. [CrossRef]

118. Mariette, X.; Rouanet, S.; Sibilia, J.; Combe, B.; Le Loët, X.; Tebib, J.; Jourdan, R.; Dougados, M. Evaluation of low-dose rituximab for the retreatment of patients with active rheumatoid arthritis: A non-inferiority randomised controlled trial. Ann. Rheum. Dis. 2014, 73, 1508-1514. [CrossRef]

119. Zaja, F.; Vianelli, N.; Volpetti, S.; Battista, M.L.; Defina, M.; Palmieri, S.; Bocchia, M.; Medeot, M.; De Luca, S.; Ferrara, F.; et al. Low-dose rituximab in adult patients with primary immune thrombocytopenia. Eur. J. Haematol. 2010, 85, 329-334. [CrossRef]

120. Gómez-Almaguer, D.; Solano-Genesta, M.; Tarín-Arzaga, L.; Herrera-Garza, J.L.; Cantú-Rodríguez, O.G.; Gutiérrez-Aguirre, C.H.; Jaime-Pérez, J.C. Low-dose rituximab and alemtuzumab combination therapy for patients with steroid-refractory autoimmune cytopenias. Blood 2010, 116, 4783-4785. [CrossRef]

121. Barcellini, W.; Zaja, F.; Zaninoni, A.; Imperiali, F.G.; Di Bona, E.; Fattizzo, B.; Consonni, D.; Cortelezzi, A.; Zanella, A. Sustained response to low-dose rituximab in idiopathic autoimmune hemolytic anemia. Eur. J. Haematol. 2013, 91, 546-551. [CrossRef] 
122. Fattizzo, B.; Zaninoni, A.; Pettine, L.; Cavallaro, F.; Di Bona, E.; Barcellini, W. Low-dose rituximab in autoimmune hemolytic anemia: 10 years after. Blood 2019, 133, 996-998. [CrossRef] [PubMed]

123. Kimby, E. Tolerability and safety of rituximab (MabThera). Cancer Treat. Rev. 2005, 31, 456-473. [CrossRef] [PubMed]

124. Gea-Banacloche, J.C. Rituximab-associated infections. Semin. Hematol. 2010, 47, 187-198. [CrossRef] [PubMed]

125. Carson, K.R.; Evens, A.M.; Richey, E.A.; Habermann, T.M.; Focosi, D.; Seymour, J.F.; Laubach, J.; Bawn, S.D.; Gordon, L.I.; Winter, J.N.; et al. Progressive multifocal leukoencephalopathy after rituximab therapy in HIV-negative patients: A report of 57 cases from the Research on Adverse Drug Events and Reports project. Blood 2009, 113, 4834-4840. [CrossRef]

126. Focosi, D.; Tuccori, M.; Maggi, F. Progressive multifocal leukoencephalopathy and anti-CD20 monoclonal antibodies: What do we know after 20 years of rituximab. Rev. Med. Virol. 2019, 29, e2077. [CrossRef]

127. Evens, A.M.; Jovanovic, B.D.; Su, Y.C.; Raisch, D.W.; Ganger, D.; Belknap, S.M.; Dai, M.S.; Chiu, B.C.; Fintel, B.; Cheng, Y.; et al. Rituximab-associated hepatitis B virus (HBV) reactivation in lymphoproliferative diseases: Meta-analysis and examination of FDA safety reports. Ann. Oncol. 2011, 22, 1170-1180. [CrossRef]

128. Tien, Y.C.; Yen, H.H.; Chiu, Y.M. Incidence and clinical characteristics of hepatitis B virus reactivation in HBsAg-negative/HBcAb-positive patients receiving rituximab for rheumatoid arthritis. Clin. Exp. Rheumatol. 2017, 35, 831-836.

129. Chen, Y.M.; Chen, H.H.; Huang, W.N.; Chen, Y.H.; Hsieh, T.Y.; Yang, S.S.; Lan, J.L.; Chen, D.Y. Reactivation of hepatitis B virus infection following rituximab treatment in HBsAg-negative, HBcAb-positive rheumatoid arthritis patients: A long-term, real-world observation. Int. J. Rheum. Dis. 2019, 22, 1145-1151. [CrossRef]

Publisher's Note: MDPI stays neutral with regard to jurisdictional claims in published maps and institutional affiliations. 